\title{
POSSIBLE FACTORS CAUSING OLDER RADIOCARBON AGE FOR BULK ORGANIC MATTER IN SEDIMENT FROM DAIHAI LAKE, NORTH CHINA
}

\author{
Yanhong $\mathrm{Wu}^{1} \cdot$ Sumin $\mathrm{Wang}^{2} \cdot$ Liping Zhou ${ }^{3}$ \\ ABSTRACT. Many factors may influence the radiocarbon age results of lacustrine sediments, among which the hardwater \\ effect is particularly important. Daihai Lake is a closed lake located in the semi-arid region of Inner Mongolia, China. High \\ concentrations of $\mathrm{HCO}_{3}{ }^{-}$and $\mathrm{CO}_{3}{ }^{2-}$ and high $\mathrm{pH}$ values in the lake water imply that there is a hardwater effect when using \\ bulk lacustrine sediment samples for ${ }^{14} \mathrm{C}$ dating. To correct the apparent ${ }^{14} \mathrm{C}$ age, we present a pilot study based on a series \\ of ${ }^{14} \mathrm{C}$ ages of lake surface sediment, lake water, submerged aquatic plant (Myriophyllum), fish bone (Cyprinus carpio), and \\ surface soil samples from and around Daihai Lake. Assuming that the relationship between the ${ }^{14} \mathrm{C} /{ }^{12} \mathrm{C}$ ratio of DIC and of \\ atmospheric $\mathrm{CO}_{2}$ was constant (at 0.816 ), the hardwater effect ages calculated for the past $8000 \mathrm{yr}$ would have varied from \\ 949 to 1788 yr. Together with the reservoir effect and soil organic matter input, the hardwater effect is a major factor causing \\ changes in apparent age when using bulk organic matter for ${ }^{14} \mathrm{C}$ dating.
}

\section{INTRODUCTION}

Radiocarbon dating is a useful method for providing a chronological sequence for PleistoceneHolocene paleoenvironmental studies. However, many studies of lacustrine and marine sediments, and even soils, have yielded older than expected ${ }^{14} \mathrm{C}$ ages (Björck et al. 1991, 1996, 2003; Gu et al. 1993; Sun et al. 1993; Rea and Colman 1995; Colman et al. 1996; Fontes et al. 1996; Wohlfarth et al. 1998; Björck and Wohlfarth 2001; Wang et al. 2002; Hutchinson et al. 2004; Peng et al. 2005; Xiao et al. 2005). The "older" ages are caused by several factors, the most important being the reservoir effect and hardwater effect, which contribute to ${ }^{14} \mathrm{C}$ depletion during dating of materials due to old carbon incorporation (Fontes et al. 1996; Björck and Wohlfarth 2001; Hall and Henderson 2001). Bulk organic matter in lacustrine sediment is widely used as ${ }^{14} \mathrm{C}$ dating material, although pollen or other microfossils can also be used. The major source of organic matter in lakes is from endogenic aquatic plants (Meyers and Ishiwatari 1993). When the lake has been efficiently sealed off from the atmosphere by lake ice, or is mainly fed by water containing old carbon from glacier water, groundwater, or from volcanic eruption, the ${ }^{14} \mathrm{C} /{ }^{12} \mathrm{C}$ ratio of the dissolved inorganic carbon (DIC) should be lower than the ${ }^{14} \mathrm{C} /{ }^{12} \mathrm{C}$ ratio of $\mathrm{CO}_{2}$ in the contemporaneous atmosphere. Thus, dating of aquatic plant materials that assimilate such DIC will be affected by the so-called "lake reservoir effect" (Björck and Wohlfarth 2001). In a hardwater lake rich in bicarbonate ions, aquatic plants will take up and incorporate some "dead" carbon, resulting in the hardwater effect (Björck and Wohlfarth 2001; Wu et al. 2006).

The hardwater effect and reservoir effect are crucial for past global-change research, when scientists try to correct the apparent ${ }^{14} \mathrm{C}$ ages of records such as lakes. To correct for the hardwater and reservoir effects, analyses are made of shells and terrestrial plant fossils (pollen, plant stems, etc.) and compared with the results of other dating methods, to get reservoir ages (Rea and Colman 1995; Ren 1998; Wohlfarth et al. 1998; Hall and Henderson 2001; Eiríksson et al. 2004; Hutchinson et al. 2004; Shackleton et al. 2004; Zhang et al. 2004; Bondevik et al. 2006; Reimer and Reimer 2006). Unfortunately, in many lacustrine sediments there are often few terrestrial plant fossils to resolve this problem. The more general way to estimate the effect is to determine the apparent age at zero depth according to a regression line based on a series of apparent ${ }^{14} \mathrm{C}$ ages (Fontes et al. 1996; Shen et al.

\footnotetext{
${ }^{1}$ Institute of Mountain Hazards and Environment, Chinese Academy of Sciences, Chengdu, 610041, China. Corresponding author. Email: yhwu@imde.ac.cn.

${ }^{2}$ State Key Laboratory of Lake Science and Environment, Nanjing Institute of Geography and Limnology, Chinese Academy of Sciences, Nanjing 210008, China.

${ }^{3}$ Laboratory for Earth Surface Processes, Department of Geography, Peking University, Beijing 100871, China.
} 
2005; Xiao et al. 2005); however, this approach does not take into account any temporal variation in the hardwater and reservoir effects. Stiller et al. (2001) calibrated the age of sediments according to the relationship between ${ }^{14} \mathrm{C}$ levels in lake water and the atmosphere in Lake Galilee during the past $10,000 \mathrm{yr}$.

Generally, ${ }^{14} \mathrm{C}$ ages are calculated according to the following equation:

$$
T=8033 \ln \left(A_{0} / A_{t}\right)
$$

where $T$ is the ${ }^{14} \mathrm{C}$ age of the sample (yr BP); $A_{0}$ is the initial activity of ${ }^{14} \mathrm{C}(\mathrm{cpm} / \mathrm{g})$; and $A_{t}$ is the ${ }^{14} \mathrm{C}$ activity measured during counting of the sample $(\mathrm{cpm} / \mathrm{g})$. The ${ }^{14} \mathrm{C}$ activity of the atmosphere is therefore regarded as $A_{0}$. For lakes where hardwater or reservoir effects exist, the ${ }^{14} \mathrm{C}$ activity of DIC may be lower than that of atmospheric $\mathrm{CO}_{2}$. The hardwater age and reservoir age thus can be calculated according to the ${ }^{14} \mathrm{C} /{ }^{12} \mathrm{C}$ ratio of DIC.

In paleoenvironmental research on Chinese lake sediments, hardwater and reservoir effects have been found widely, especially in some high-salinity and high-pH lakes on the Tibetan Plateau and other arid and semi-arid areas (Gu et al. 1993; Sun et al. 1993; Fontes et al. 1996; Wang et al. 2002; Shen et al. 2005). In Daihai Lake, Inner Mongolia, north China, Cao et al. (2000) noticed large discrepancies in the sediment rate of the upper layers between ${ }^{210} \mathrm{~Pb}$ results and ${ }^{14} \mathrm{C}$ dates and attributed them to the uncertainties associated with different dating methods. Xiao et al. (2005) discovered the existence of a hardwater effect in $8{ }^{14} \mathrm{C}$ dating results (using bulk organic matter as dating material), and deduced a hardwater age of $360 \mathrm{yr}$ according to a linear regression, taking the age of $0 \mathrm{yr}$ for the surface sediment. Our preliminary study on surficial samples from the same lake, however, revealed apparently more pronounced deviation from zero age, which was initially attributed to the reservoir effect (Wu et al. 2007).

Here, we present a summary of the ${ }^{14} \mathrm{C}$ dating results of surface sediment, live aquatic plants, bones of live fish, lake water, and lake beach soil samples from Daihai Lake, and discuss possible factors causing apparently older ${ }^{14} \mathrm{C}$ ages and the possible approaches to correct them.

\section{GENERAL DESCRIPTION OF THE RESEARCH AREA}

Daihai Lake $\left(112^{\circ} 33^{\prime} 31^{\prime \prime}\right.$ to $112^{\circ} 46^{\prime} 40^{\prime \prime} \mathrm{E}, 40^{\circ} 29^{\prime} 7^{\prime \prime}$ to $\left.40^{\circ} 37^{\prime} 6^{\prime \prime} \mathrm{N}\right)$ lies about $10 \mathrm{~km}$ east of Liangcheng County, Inner Mongolia, in north-central China (Figure 1). It has an area of $160 \mathrm{~km}^{2}$ with a maximum water depth of $16 \mathrm{~m}$ and an elevation of $1221 \mathrm{~m}$. It is a semi-brackish closed lake, the major inflows of which are the Muhua River, forming the east bank, and the Gongba River, forming the west bank (Wang et al. 1990).

Daihai Lake is located at the transition between semi-humid and semi-arid areas in the middle temperate zone of China. The mean annual temperature is $5.1^{\circ} \mathrm{C}$ with a July average of $20.5^{\circ} \mathrm{C}$ and a January average of $13.0^{\circ} \mathrm{C}$ (Xiao et al. 2005). The mean annual precipitation is $413 \mathrm{~mm}$, about $80 \%$ of which occurs in summer. The mean annual evaporation reaches $1033 \mathrm{~mm}$ (Wang et al. 1990).

Because the evaporation is much higher than precipitation and the water consumption in the catchment has increased during the past several decades, the lake shrank and the salinity of the lake water increased continuously. The salinity was $2100-2400 \mathrm{mg} / \mathrm{L}$ in $1963, \sim 3000 \mathrm{mg} / \mathrm{L}$ in 1987 (Wang et al. 1990), and increased to 3888 to $5120 \mathrm{mg} / \mathrm{L}$ as measured in 2006 and 2007 (Table 1). The $\mathrm{pH}$ value also increased during the past several decades (Wang et al. 1990). 


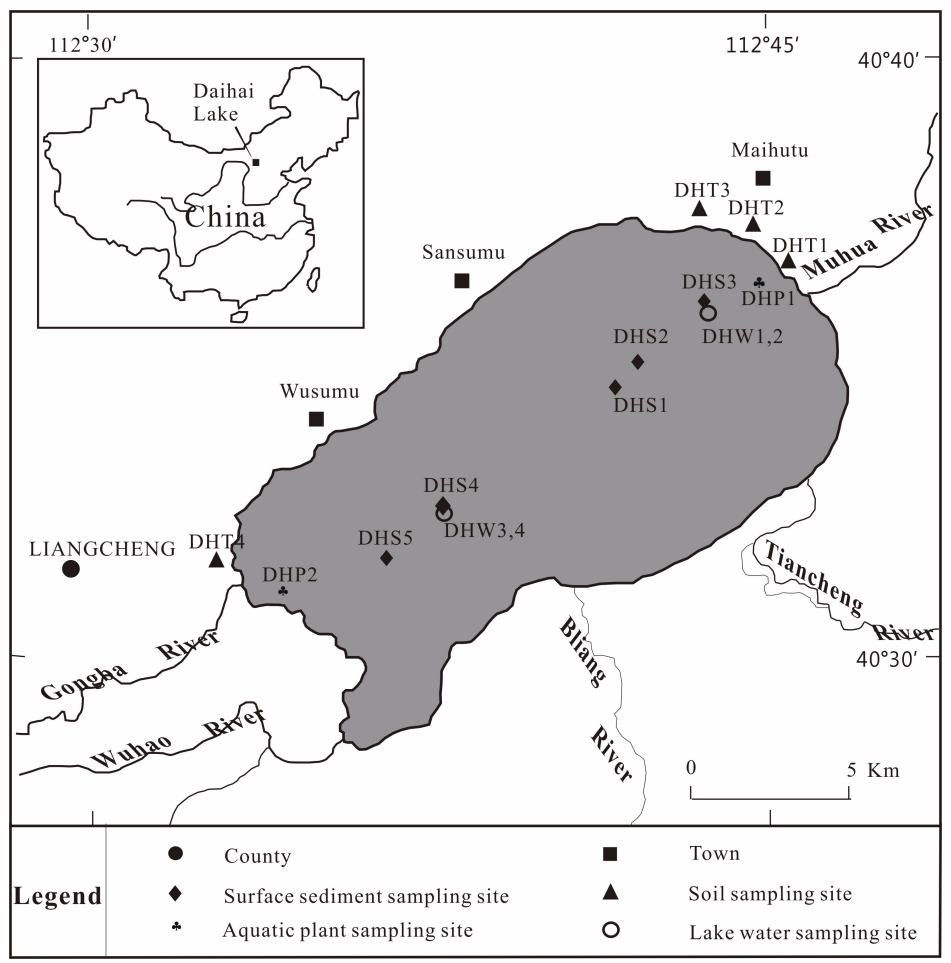

Figure 1 Map of Daihai Lake and the sampling sites

Table 1 Results of ${ }^{14} \mathrm{C}$ levels of different samples and their apparent ${ }^{14} \mathrm{C}$ ages (half-life $5730 \mathrm{yr}$ ). ${ }^{\mathrm{a}}$

\begin{tabular}{|c|c|c|c|c|c|c|}
\hline Sample type & Sample nr & Material $^{b}$ & $X_{s}$ & $X_{s} / X_{a}$ & $\begin{array}{l}\text { Apparent } \\
{ }^{14} \mathrm{C} \text { age } \\
(\mathrm{yr} \mathrm{BP})\end{array}$ & $\begin{array}{l}\text { Age } \\
\text { uncertainty } \\
\text { (yr) }\end{array}$ \\
\hline \multirow[t]{5}{*}{ Surface sediments } & DHS1 & $\mathrm{OM}_{\text {bulk }}$ & 1.087 & 0.798 & 1865 & 40 \\
\hline & DHS2 & $\mathrm{OM}_{\text {bulk }}$ & 1.065 & 0.782 & 2035 & 40 \\
\hline & DHS3 & $\mathrm{OM}_{\text {bulk }}$ & 1.061 & 0.779 & 2065 & 50 \\
\hline & DHS4 & $\mathrm{OM}_{\text {bulk }}$ & 1.052 & 0.773 & 2132 & 50 \\
\hline & DHS5 & $\mathrm{OM}_{\text {bulk }}$ & 1.086 & 0.797 & 1871 & 40 \\
\hline \multirow[t]{2}{*}{ Submerged plants } & DHP1 & $\mathrm{OM}_{\text {bulk }}$ & 1.003 & 0.737 & 2528 & 80 \\
\hline & DHP2 & $\mathrm{OM}_{\text {bulk }}$ & 1.086 & 0.798 & 1870 & 70 \\
\hline \multirow[t]{4}{*}{ Water } & DHW1 & TIC & 1.143 & 0.839 & 1450 & 125 \\
\hline & DHW2 & TIC & 1.088 & 0.799 & 1860 & 80 \\
\hline & DHW3 & TIC & 1.103 & 0.81 & 1740 & 70 \\
\hline & DHW4 & TIC & 1.11 & 0.815 & 1690 & 70 \\
\hline Fish bone & DHF1 & $\mathrm{OM}_{\text {bulk }}$ & 1.005 & 0.738 & 2513 & 70 \\
\hline \multirow[t]{4}{*}{ Surrounding soil } & DHT1 & $\mathrm{OM}_{\text {bulk }}$ & 1.005 & 0.738 & 2513 & 90 \\
\hline & DHT2 & $\mathrm{OM}_{\text {bulk }}$ & 1.167 & 0.857 & 1277 & 80 \\
\hline & DHT3 & $\mathrm{OM}_{\text {bulk }}$ & 1.058 & 0.777 & 2090 & 90 \\
\hline & DHT4 & $\mathrm{OM}_{\text {bulk }}$ & 1.147 & 0.842 & 1420 & 80 \\
\hline
\end{tabular}

${ }^{\mathrm{a}} X_{S}={ }^{14} \mathrm{C}$ activity of measured sample; $X_{a}={ }^{14} \mathrm{C}$ activity of atmosphere.

${ }^{\mathrm{b}} \mathrm{OM}_{\text {bulk }}=$ bulk organic matter; TIC $=$ total inorganic carbon. 


\section{MATERIALS AND METHODS}

Three surface sediment samples (DHS1, DHS2, and DHS3) from the eastern part of Daihai Lake were collected using a gravity corer in April 2006, and undisturbed surface 2-cm sediments were used for ${ }^{14} \mathrm{C}$ dating. Another 2 samples (DHS4 and DHS5) from the western part of Daihai Lake were collected in June 2007 using the same method as the former 3 samples. Two aquatic plant (Myriophyllum) samples were collected from the east and west ends of the lake in April 2006. A live fish (Cyprinus carpio) was captured by a fisherman when we collected surface sediments in April 2006. The fish bone was collected and the flesh discarded. A water sample (DHW1) was collected $1 \mathrm{~m}$ below the water surface, while sample DHW2 was collected at $9 \mathrm{~m}$ depth, in the same location as DHW1. Another 2 water samples (DHW3 at $1 \mathrm{~m}$ depth and DHW4 at $7 \mathrm{~m}$ depth) from the same site in the western part of Daihai Lake were collected in June 2007. Four soil samples (DHT1 to DHT4) were taken from the beach $10 \mathrm{~cm}$ beneath the surface.

Surface sediments and soil samples were treated with $5 \% \mathrm{HCl}$ to remove inorganic carbon after manually removing visible plant remains and roots. Samples were then burnt with excess oxygen at $400{ }^{\circ} \mathrm{C}$ to combust bulk organic matter (McGeehin et al. 2001). Aquatic plant samples and fish bones were cleaned with $5 \% \mathrm{HCl}$ and washed with distilled water several times, then freeze-dried before burning with excess oxygen at $400{ }^{\circ} \mathrm{C}$ to extract $\mathrm{CO}_{2}$ from the bulk organic matter. Water samples were sealed in glass vessels and added excess $\mathrm{CaCl}_{2}$ as soon as samples were taken, and boiled thereafter to obtain crystal $\mathrm{CaCO}_{3}$ as ${ }^{14} \mathrm{C}$ dating material.

DHS1 and DHS2 were dated at Peking University using accelerator mass spectrometry (AMS). The other samples were dated in State Key Laboratory of Lake Science and Environment, Nanjing Institute of Geography and Limnology, Chinese Academy of Sciences, using liquid scintillation counting (LSC). The measured ${ }^{14} \mathrm{C}$ activities of samples were noted as $X_{s}$ and expressed as ratios relative to the ${ }^{14} \mathrm{C}$ standard specific activity of carbon of Chinese sugar (1970), which is 1.362 times the specific activity of the NBS oxalic acid standard using the ${ }^{14} \mathrm{C}$ half-life of $5730 \mathrm{yr}$ (Qiu et al. 1990).

\section{RESULTS}

${ }^{14} \mathrm{C}$ activity of the sampled surface sediments, fish bones, aquatic plants, DIC of lake water and beach soil varied between 1.003 and 1.147. Their apparent ${ }^{14} \mathrm{C}$ ages were calculated according to Equation 1 (Figure 2, Table 1). The apparent ${ }^{14} \mathrm{C}$ age of the fish bone was $2513 \pm 73 \mathrm{yr}$ BP. Aquatic plants in the east part of Daihai Lake were much older than that in western part, being $2528 \pm 84$ and $1870 \pm 70 \mathrm{yr} \mathrm{BP}$, respectively. The apparent ${ }^{14} \mathrm{C}$ ages of surface sediment varied between 1865 and $2132 \mathrm{yr}$ BP. The bulk soil samples' apparent ${ }^{14} \mathrm{C}$ ages varied remarkably between $1277 \pm 77$ and $2510 \pm 90 \mathrm{yr}$ BP. There was little difference in apparent ${ }^{14} \mathrm{C}$ ages at different depths in the same site, but the average apparent ${ }^{14} \mathrm{C}$ ages of lake water in the eastern and western part of Daihai Lake changed little (1655 and $1715 \mathrm{yr} \mathrm{BP}$, respectively). All the ${ }^{14} \mathrm{C}$ data showed an "older" apparent age than expected, since the expected real age of surface sediments should be $0 \mathrm{yr}$.

\section{DISCUSSION}

Daihai Lake is a closed lake in which the residence time of lake water is very long. The evaporation is about 2.5 times the precipitation; therefore, the salinity and $\mathrm{pH}$ value are very high $(\sim 9.0)$ (Wu et al. 2007). The concentration of $\mathrm{HCO}_{3}{ }^{-}$is between 387.4 and $499.9 \mathrm{mg} / \mathrm{L}$ with an average value of $460.3 \mathrm{mg} / \mathrm{L}$, while the concentration of $\mathrm{CO}_{3}{ }^{2-}$ varies between 102.6 and $174.5 \mathrm{mg} / \mathrm{L}$ with an average value of $120.9 \mathrm{mg} / \mathrm{L}$. All the lake water chemical characteristics imply that there should be a hardwater effect (Björck and Wohlfarth 2001), which is expected to be the major factor causing the older ${ }^{14} \mathrm{C}$ age of the lake sediment. 


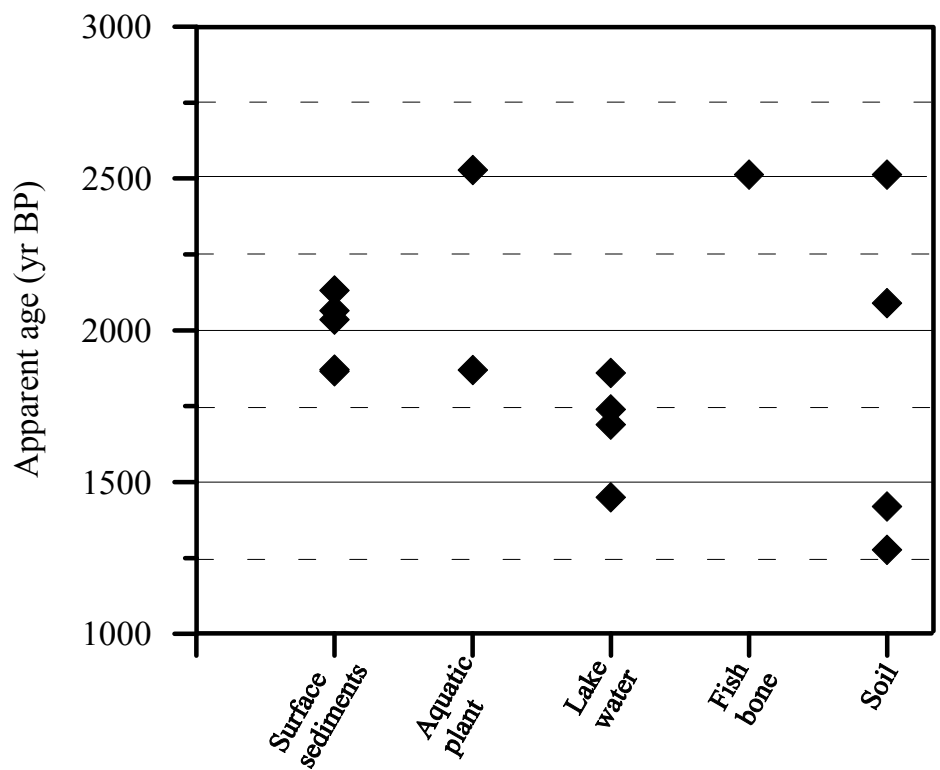

Figure 2 Apparent ${ }^{14} \mathrm{C}$ ages of surface sediment, aquatic plant, lake water, fish bone, and beach soil samples from Daihai Lake.

Based on the results of 4 lake water samples, the average ${ }^{14} \mathrm{C}$ activity level is 1.11 and the ratio of ${ }^{14} \mathrm{C}$ activity between lake water and atmospheric $\mathrm{CO}_{2}\left(X_{w} / X_{a}\right)$ is 0.816 . The hardwater effect ages of Daihai Lake can be calculated after Equation 1, as Stiller et al. (2001) have done in Lake Kinneret, on the assumption that $X_{w} / X_{a}$ was constant in the past (Figure 3). The corresponding atmospheric ${ }^{14} \mathrm{C}$ levels are taken from Stuiver and Pearson (1993) and Pearson and Stuiver (1993). The hardwater effect ages varied between 949 to 1788 yr since $8000 \mathrm{yr}$ BP, and increased notably from 5500 to 1000 yr BP.

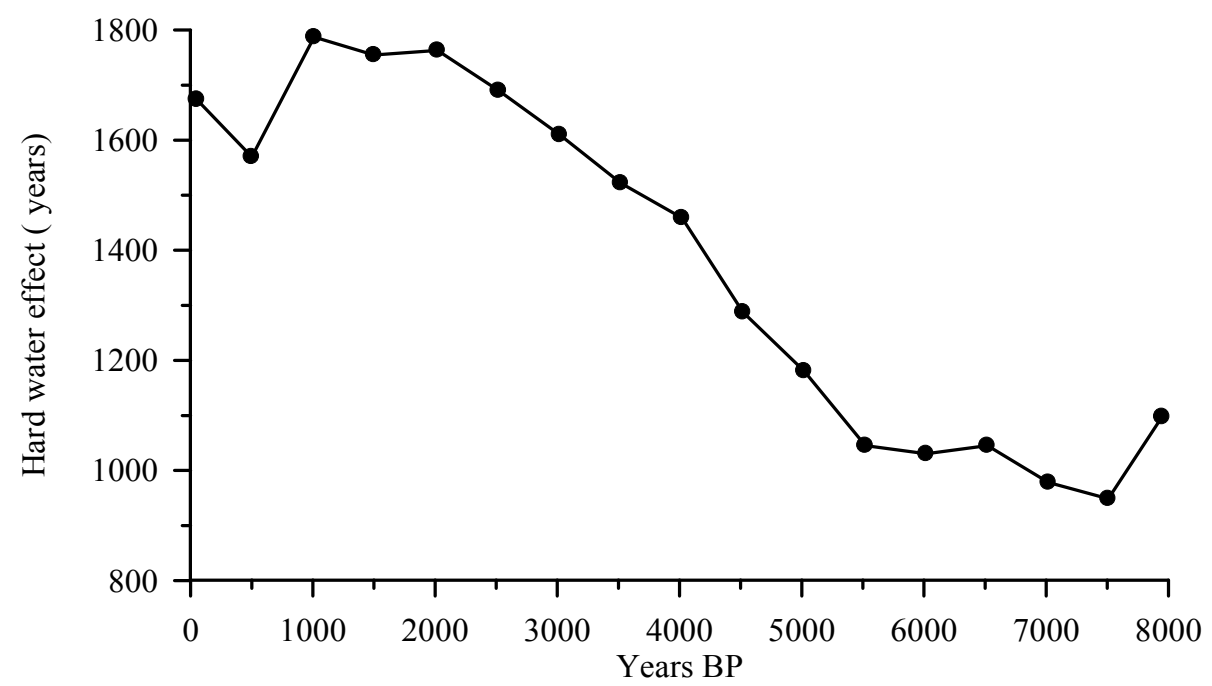

Figure 3 Inferred temporal variation of the hardwater effect in Daihai Lake since $8000 \mathrm{yr}$ BP. The corresponding atmospheric ${ }^{14} \mathrm{C}$ levels are taken from Stuiver and Pearson (1993) and Pearson and Stuiver (1993). 
The apparent ${ }^{14} \mathrm{C}$ ages of beach soil samples are generally older than their real ages. The possible interpretations include: 1 ) the sampling site was submerged in the past and the soil was formed from lake sediments according to the field investigation. Based on analyses of sedimentology, mineralogy, palynology, micropaleontology, and geochemistry of the core sediments, Wang et al. (1990) inferred that Daihai Lake maintained a high lake level at times of the Riss-Würm interglaciation and the early to middle Holocene, but assumed a general trend of contraction during the whole Late Pleistocene. Three beds of dark-colored mud deposited during the early to middle Holocene were considered to represent 3 episodes of extension of the lake around $10,000,6500$, and $4500{ }^{14} \mathrm{C} \mathrm{yr} \mathrm{BP}$, respectively (Wang et al. 1990). The sites of 4 soil samples are close to the lake shore (Figure 1) and less than half a meter above the modern lake level, so that these sites could have been submerged during their history. 2) If the soil was formed in terrestrial conditions, the soil carbon can contain both recent terrestrial plant material and older residual carbon that is protected from decay either in aggregates or in organic-mineral complexes (Huang 2001).

Since Daihai Lake is a closed lake without any outflow, the water residence time should be very long, although no relevant study has been done thus far. The lake is covered with $\sim 50 \mathrm{~cm}$ of ice from November to March (Xiao et al. 2005). We suggest that the possible factors causing the "older" ${ }^{14} \mathrm{C}$ age of lake sediments relate to the source of organic matter. The major source of organic matter in lake sediment is from endogenous plants (Meyers and Ishiwatari 1993); however, soil organic matter can be a substantial portion (Mayr et al. 2005). Thus, the hardwater effect, isotopic fractionation of aquatic plants, the reservoir effect, as well as soil organic matter together impact the ${ }^{14} \mathrm{C}$ age of lake sediments. Taking the hardwater effect and soil organic matter into account, we suggest that the correction age for lake sediment from Daihai Lake varied between 1000 and $2000 \mathrm{yr}$ since $8000 \mathrm{BP}$, and stronger reservoir effects occurred since $5500 \mathrm{BP}$ when the shrinkage of Daihai Lake began (Wang et al. 1990). This correction age is based on the presumption of a constant $X_{w} / X_{a}$. If we can get precise variation of $X_{w} / X_{a}$, for instance, when we can collect enough pore water for ${ }^{14} \mathrm{C}$ measurement, it should be possible to achieve a more accurate correction age.

\section{CONCLUSION}

Due to high salinity, high concentrations of $\mathrm{HCO}_{3}{ }^{-}$and $\mathrm{CO}_{3}{ }^{2-}$, and high $\mathrm{pH}$ value, we observe a hardwater effect in Daihai Lake. On the assumption that the relationship between the ${ }^{14} \mathrm{C} /{ }^{12} \mathrm{C}$ ratio of DIC and of atmospheric $\mathrm{CO}_{2}$ was constant, the hardwater effect ages in the past can be estimated by correlation with atmospheric ${ }^{14} \mathrm{CO}_{2}$. In Daihai Lake, the $X_{w} / X_{a}$ of present lake water is 0.816 , and the hardwater effect ages during the past $8000 \mathrm{yr}$ varied from 949 to 1788 . We suggest that the hardwater effect is the major factor that has impacted the ${ }^{14} \mathrm{C}$ age profile of lake sediments in Daihai Lake.

\section{ACKNOWLEDGMENTS}

This work was supported by the Hundred Talents Program of the Chinese Academy of Sciences and the Chinese National Natural Science Foundation (Key project, grant No. 90411017). We thank Prof Bin Xue and Prof Zhangdong Jin for their help during the fieldtrip. The authors wish to thank Prof $\mathrm{S}$ Colman and Prof T Jull for their constructive comments.

\section{REFERENCES}

Björck S, Wohlfarth B. 2001. ${ }^{14} \mathrm{C}$ chronostratigraphic techniques in paleolimnology. In: Last WM, Smol JP, editors. Tracking Environmental Change Using Lake Sediments. Dordrecht: Kluwer Academic. p 205-45.
Björck S, Hjort C, Ingolfsson O, Skog G. 1991. Radiocarbon dates from Antarctic Peninsula region - problems and potential. Quaternary Proceedings 1:55-65.

Björck S, Kromer B, Johnsen S, Bennike O, Hammar- 
lund D, Lemdahl G, Possnert G, Rasmussen TL, Wohlfarth B, Hammer CU, Spurk M. 1996. Synchronized terrestrial-atmospheric deglacial records around the North Atlantic. Science 274(5290):1155-60.

Björck S, Koç N, Skog G. 2003. Consistently large marine reservoir ages in the Norwegian Sea during the Last Deglaciation. Quaternary Science Reviews 22(57):429-35.

Bondevik S, Mangerud J, Birks HH, Gulliksen G, Reimer P. 2006. Changes in North Atlantic radiocarbon reservoir ages during the Allerød and Younger Dryas. Science 312(5779):1514-7.

Cao J, Wang S, Shen J, Zhang Z. 2000. The paleoclimate changes during the past millennium inferred from the lacustrine core in Daihai Lake, Inner Mongolia. Scientia Geographica Sinica 23:391-6.

Colman SM, Jones GA, Rubin M. 1996. AMS radiocarbon analyses from Lake Baikal, Siberia: challenges of dating sediments from a large, oligotrophic lake. Quaternary Geochronology 15(7):669-84.

Eiríksson J, Larsen G, Knudsen KL, Heinemeier J, Súmonarson LA. 2004. Marine reservoir age variability and water mass distribution in the Iceland Sea. Quaternary Science Reviews 23(20-22):2247-68.

Fontes J, Gasse F, Gibert E. 1996. Holocene environmental changes in Lake Bangong basin (western Tibet). Part 1: chronology and stable isotopes of carbonates of a Holocene lacustrine core. Palaeogeography, Palaeoclimatology, Palaeoecology 120(1-2):25-47.

Gu Z, Liu J, Yuan B, Liu D, Liu R, Liu Y, Zhang G. 1993. The changes in monsoon influence in the Qinghai-Tibetan Plateau during the past 12000 years-geochemical evidence from L. Silling Co sediments. Chinese Science Bulletin 38(1):61-4.

Hajdas I. 2006. ${ }^{14} \mathrm{C}$ chronology. PAGES Newsletter 14(3):2.

Hall BL, Henderson GM. 2001. Use of uranium-thorium dating to determine past ${ }^{14} \mathrm{C}$ reservoir effects in lakes: examples from Antarctica. Earth and Planetary Science Letters 193(3-4):565-77.

Huang C. 2001. Pedology. Beijing: Chinese Agriculture Press. p 263-311.

Hutchinson I, James TS, Reimer PJ, Bornhold BD, Clague JJ. 2004. Marine and limnic radiocarbon reservoir corrections for studies of late- and postglacial environments in Georgia Basin and Puget Lowland, British Columbia, Canada and Washington, USA. Quaternary Research 61(2):193-203.

McGeehin J, Burr GS, Jull AJT, Reines D, Gosse J, Davis PT, Muhs D, Southon JR. 2001. Stepped-combustion ${ }^{14} \mathrm{C}$ dating of sediment: a comparison with established techniques. Radiocarbon 43(2A):255-61.

Mayr C, Fey M, Haberzettl T, Janssen S, Lücke A, Maidana NI, Ohlendorf C, Schäbitz F, Schleser GH, Struck U, Wille M, Zolitschka B. 2005. Palaeoenvironmental changes in southern Patagonia during the last millennium recorded in lake sediments from $\mathrm{La}$ - guna Azul (Argentina). Palaeogeography, Palaeoclimatology, Palaeoecology 228(3-4):203-27.

Meyers PA, Ishiwatari R. 1993. Lacustrine organic geochemistry: an overview of indicators of organic matter sources and diagenesis in lake sediments. Organic Geochemistry 20:867-900.

Pearson GW, Stuiver M. 1993. High-precision bidecadal calibration of the radiocarbon time scale, 500-2500 BC. Radiocarbon 35(1):25-33.

Peng Y, Xiao J, Nakamura T, Liu B, Inouchi Y. 2005. Holocene East Asian monsoonal precipitation pattern revealed by grain-size distribution of core sediments of Daihai Lake in Inner Mongolia of north-central China. Earth and Planetary Science Letters 233(3-4):46779.

Qiu S, Chen T, Cai L. 1990. Geochronology of ${ }^{14} \mathrm{C}$ in China. Beijing: Science Press. p 1-12.

Rea DK, Colman MS. 1995. Radiocarbon ages of prebomb clams and the hard-water effect in Lakes Michigan and Huron. Journal of Paleolimnology 14:89-91.

Reimer RW, Reimer PJ. 2006. Marine reservoir corrections and the calibration curve. PAGES Newsletter 14(3):12-3.

Ren G. 1998. A finding of influence of "hard water" on radiocarbon dating for lake sediments in Inner Mongolia, China. Journal of Lake Science 10(3):80-2.

Shackleton NJ, Fairbanks RG, Chiu T, Parrenin F. 2004. Absolute calibration of the Greenland time scale: implications for Antarctic time scales and for $\Delta^{14} \mathrm{C}$. Quaternary Science Reviews 23(14-15):1513-22.

Shen J, Liu X, Wang S. 2005. Palaeoclimatic changes in the Qinghai Lake area during the last 18,000 years. Quaternary International 136(1):131-40.

Stiller M, Kaufmann A, Carmi I, Mintz G. 2001. Calibration of lacustrine sediment ages using the relationship between ${ }^{14} \mathrm{C}$ levels in lake waters and in the atmosphere: the case of Lake Kinneret. Radiocarbon 43(2B):821-30.

Stuiver M, Pearson GW. 1993. High-precision bidecadal calibration of the radiocarbon time scale AD 1950500 BC and 2500-6000 BC. Radiocarbon 35(1):1-23.

Sun X, Du N, Chen Y, Gu Z, Liu J, Yuan B. 1993. Analysis on pollen of lake sediment in Silling Co, Tibet. Acta Botanica Sinica 35(12):943-50.

Wang RL, Scarpitta SC, Zhang SC. 2002. Later Pleistocene/Holocene climate conditions of Qinghai-Xizang Plateau (Tibet) based on carbon and oxygen stable isotopes of Zabuye lake sediments. Earth and Planetary Letters 203(1):461-77.

Wang S, Yu Y, Wu R. 1990. The Daihai Lake: Environment Evolution and Climate Change. Hefei: University of Science and Technology of China Press. p 122.

Wohlfarth B, Skog G, Possnert G, Holmquist B. 1998. Pitfalls in the AMS radiocarbon-dating of terrestrial macrofoffils. Journal of Quaternary Science 13(2): 137-45. 
Wu Y, Wang S, Hou X. 2006. Chronology of Holocene lacustrine sediments events in Cuoe Lake, central Tibetan Plateau. Science in China D 49(9):991-1001.

Wu YH, Wang SM, Zhou LP, Zhang ZB. 2007. Modern reservoir age for C-14 dating in Daihai Lake. Quaternary Sciences 27:507-10. In Chinese.

Xiao J, Xu Q, Nakamura T, Yang X, Liang W, Inouchi Y. 2005. Holocene vegetation variation in the Daihai
Lake region of north-central China: a direct indication of the Asian monsoon climatic history. Quaternary Science Reviews 23(14-15):1669-79.

Zhang C, Cao J, Lei Y. 2004. The chronological characteristics of Bosten Lake Holocene sediment environment in Xinjiang, China. Acta Sedimentologica Sinica 22(3):494-9. 